University of Nebraska - Lincoln

DigitalCommons@University of Nebraska - Lincoln

2009

\title{
Mechanistic effect models for ecological risk assessment of chemicals (MEMoRisk) - A new SETAC-Europe Advisory Group
}

Thomas G. Preuss

Aachen University, thomas.preuss@bio5.rwth-aachen.de

Udo Hommen

Fraunhofer IME, Schmallenberg, Germany

Anne Alix

AFFSA, Direction du Végétal et de l'Environnement, Maisons Alfort, France

Roman Ashauer

Eawag, Dübendorf, Switzerland

Paul van den Brink

Wageningen University

See next page for additional authors

Follow this and additional works at: https://digitalcommons.unl.edu/biosciforbes

Part of the Pharmacology, Toxicology and Environmental Health Commons

Preuss, Thomas G.; Hommen, Udo; Alix, Anne; Ashauer, Roman; van den Brink, Paul; Chapman, Peter; Ducrot, Virginie; Forbes, Valery E.; grimm, Volker; Schäfer, Dieter; Streissl, Franz; and Thorbek, Pernille, "Mechanistic effect models for ecological risk assessment of chemicals (MEMoRisk) - A new SETACEurope Advisory Group" (2009). Valery Forbes Publications. 15.

https://digitalcommons.unl.edu/biosciforbes/15

This Article is brought to you for free and open access by the Papers in the Biological Sciences at DigitalCommons@University of Nebraska - Lincoln. It has been accepted for inclusion in Valery Forbes Publications by an authorized administrator of DigitalCommons@University of Nebraska - Lincoln. 


\section{Authors}

Thomas G. Preuss, Udo Hommen, Anne Alix, Roman Ashauer, Paul van den Brink, Peter Chapman, Virginie Ducrot, Valery E. Forbes, Volker grimm, Dieter Schäfer, Franz Streissl, and Pernille Thorbek 
Published in Environmental Science and Pollution Research 16 (2009), pp. 250-252; doi: 10.1007/s11356-009-0124-6

Copyright (C) 2009 Springer-Verlag. Used by permission.

Submitted February 23, 2009; accepted March 5, 2009; published online March 26, 2009.

\title{
Mechanistic effect models for ecological risk assessment of chemicals (MEMoRisk) - A new SETAC-Europe Advisory Group
}

\author{
Thomas G. Preuss, ${ }^{1}$ Udo Hommen, ${ }^{2}$ Anne Alix, ${ }^{3}$ Roman Ashauer, ${ }^{4}$ \\ Paul van den Brink, ${ }^{5}$ Peter Chapman, ${ }^{6}$ Virginie Ducrot, ${ }^{7}$ Valery Forbes, ${ }^{8}$ \\ Volker Grimm, ${ }^{9}$ Dieter Schäfer, ${ }^{10}$ Franz Streissl, ${ }^{11}$ and Pernille Thorbek ${ }^{12}$
}

1. Institute for Environmental Research, RWTH Aachen University, Worringerweg 1, 52056 Aachen, Germany

2. Fraunhofer IME, Auf dem Aberg 1, 57392 Schmallenberg, Germany

3. AFFSA, Direction du Végétal et de l'Environnement (Plant and Environment Directorate), 10 rue Pierre Curie, 94704 Maisons Alfort, France

4. Eawag, Überlandstrasse 133, Postfach 611, 8600 Dübendorf, Switzerland

5. Alterra, Wageningen University and Research Centre, P. O. Box 47, 6700 AA Wageningen, The Netherlands

6. Unilever - Safety \& Environmental Assurance Centre, Unilever House, Blackfriars, London, UK

7. INRA, Agrocampus Ouest, UMR985 Ecologie et Santé des Ecosystèmes, Équipe Écotoxicologie et Qualité des Milieux Aquatiques, 65 rue de Saint Brieuc, 35000 Rennes, France

8. Center for Integrated Population Ecology, Roskilde University, 4000 Roskilde, Denmark

9. Department of Ecological Modelling, UFZ, Helmholtz Centre for Environmental Research - UFZ, Permoserstr. 15, 04318 Leipzig, Germany

10. Bayer CropScience, Environmental Safety, Alfred-Nobel-Str. 50, Geb. 6650, 40789 Monheim, Germany

11. EFSA (European Food Safety Authority), Pesticide Risk Assessment Peer Review (PRAPeR), Largo N. Palli 5/A, 43100 Parma, Italy

12. Syngenta, Environmental Safety, Jealott's Hill, International Research Centre, Bracknell, Berkshire, RG42 6EY, UK

Corresponding author - Thomas G. Preuss, email thomas.preuss@bio5.rwth-aachen.de

Thomas G. Preuss and Udo Hommen contributed equally to this article.

\section{Background}

Mechanistic effect models have been applied to ecotoxicological questions for over 25 years (e.g. O'Neill et al. 1982; Kooijman and Metz 1984; Pastorok et al. 2003), but their use in regulatory risk assessment has been very limited so far. Recently, the value of models in support of regulatory ecological risk assessments is being recognized. Thus, such models were mentioned as valuable higher tier tools in several recent expert workshops on risk assessment of pesticides under the European Directive $91 / 414$, i.e. the SETAC workshops AMPERE on me- 
socosm tests (Alix et al. 2007) and AMRAP on macrophyte testing (Maltby et al. 2009). The ELINK workshop focused on how to extrapolate from the usually simple exposure patterns in ecotoxicological test systems to the complex exposure scenarios predicted by the exposure models that are used in risk assessments, and different types of effect models were discussed for the potential use to solve this problem (Hommen et al. 2009). Finally, the LEMTOX workshop (Forbes et al. 2009; Thorbek et al. 2009) was organized especially to bring together international experts from Europe, Japan, and North America to discuss the pros and cons of using ecological models (mainly population models) for pesticide risk assessments.

Generally, the uses of such models are not restricted to pesticides. Within a project sponsored by the CEFIC Long Research Initiative, the protection goals of the different European Directives for chemicals, including plant protection products, biocidal products, pharmaceutical products for human or veterinary use and industrial chemicals, have been reviewed to identify the relevant main areas of application for mechanistic effect models in chemical risk assessment (Galic et al. 2008): clarifying ecological relevance of observed effects (usually on the level of individual organisms) in standard laboratory tests for risk at the population level (e.g. the relevance of the effects on reproduction or growth of fish for the sustainability of populations); extrapolating effects from an experimentally tested exposure to other untested exposure patterns (e.g. from the tested one-peak exposure in a mesocosm to the multiple peak exposure profile predicted for field conditions caused by multiple drift, run-off and drainage events); extrapolating recovery processes (e.g. from intrinsic recovery tested in a mesocosm study to recovery, including recolonization in an agricultural landscape or from observed effects and recovery of species experimentally tested to effects and recovery of untested species with different life cycle types); analysis and prediction of possible indirect effects in communities (by the use of dynamic community or ecosystem models); and prediction of bioaccumulation within food chains and food webs.

\section{Aim and scope of the new advisory group}

Recent reviews of the state-of-the-art of ecological modeling for risk assessments have highlighted the need for standardization of modeling approaches (Pastorok et al. 2003; Grimm et al. 2009). Such standardization requires concerted actions with all stakeholders involved in the regulatory process.

Therefore, a new SETAC-Europe Advisory Group on "Mechanistic effect models for ecological risk assessment of chemicals" (MEMoRisk) was established in autumn 2008. During the SETAC-Europe Annual Meeting in Warsaw in May 2008, 21 people joined the founding meeting where the necessity, scope and aim of such a group were discussed. A founding steering committee (the authors of this paper) was selected to prepare a proposal and to bring the advisory group into life.

The overall aim of the advisory group is to explore and evaluate the benefit of mechanistic effect modeling for the risk assessment of chemicals in Europe and elsewhere as appropriate. This will be done by establishing a forum for better communication and cooperation of scientists in academia, industry and government working on or with mechanistic modeling to analyze and predict effects of chemicals on organisms, populations and communities.

Within the scope of MEMoRisk are models to analyze and predict effects of chemicals on organisms, populations, communities and ecosystems in aquatic, soil and terrestrial environments. The term ecological modeling is avoided here because it is often used for population, community, food web and ecosystem models, but MEMoRisk will also consider models that describe and predict effects on the level of the single organism, e.g. toxicokinetic and toxicodynamic models, dynamic energy budget models, biotic ligand models. Empirical statistical models (e.g. dose-response functions, species sensitivity distributions, multivariate models of community structure) and QSARs, however, are outside the scope of MEMoRisk.

MEMoRisk will establish a web-based forum for discussion as well as for providing access to relevant information (e.g. links to workshop reports, guidance documents, reviews, and books). Later on, the group will organize session(s) and/or short courses. Valery Forbes, Roman Ashauer and Pernille Thorbek will chair a session on "Mechanistic effect models for ecological risk assessment" at the SETAC-Europe Meeting in Goteborg, June 2009. MEMoRisk Advisory Group will be actively involved in organizing expert workshops, e.g. on the development of guidance documents on the use of modeling in ecological risk assessment in support of European legislation. The MEMoRisk Advisory Group will also actively be involved in the upcoming EU funded project CREAM ("Mechanistic Effect Models for Ecological Risk Assessment of Chemicals"), a Marie Curie Initial Training Network including more than 20 partners from academia, industry and regulatory authorities from eight European countries. CREAM will start in summer 2009 (coordinator: V. Grimm; work packages leaders: P. Thorbek, V. Forbes, U. Hommen, P. van den Brink).

\section{Contact}

The Advisory Group is open to all interested scientists and students. The next meeting of the Group will be 
held during the 19th SETAC-Europe Annual Meeting in Göteborg. More information can be found on the SETAC Website at http://www.setac.org/node/11.

\section{References}

Alix A, Heimbach F, Liess M, Maltby L, Maund S, Wogram J (eds) (2007) Aquatic Mesocosms in Pesticide Registration in Europe: Recent Experiences (AMPERE). Summary of the AMPERE workshop in Leipzig, Germany, 24-25 April 2007. http://www.systemecology.eu/AMPERE/Summary_files/AMPERE_summary.pdf

Forbes VE, Hommen U, Thorbek T, Heimbach F, van den Brink PJ, Wogram J, Thulke HH, Grimm V (2009) Ecological models in support of regulatory risk assessments of pesticides: developing a strategy for the Future. Integrated Environ Assess Manag 5(1):167-172

Galic N, Van den Brink PJ, Baveco H, Hommen U, Schaefers C (2008) Do existing population models meet the needs of current risk assessment schemes for pesticides and biocides? Abstract. SETAC Europe 18th Annual Meeting, Warsaw, Poland, 25-29.05.2008

Grimm V, Thorbek P, Schmolke A, Chapman P (2009) Stateof-the-art of ecological modelling for pesticide risk assessment: a critical review. In: Thorbek P, Forbes V, Heimbach F, Hommen U, Thulke HH, van den Brink P, Wogram J, Grimm V (eds) Ecological models in support of regulatory risk assessments of pesticides: developing a strategy for the future. SETAC, Pensacola (in press)
Hommen U, Ashauer R, van den Brink P, Caquet T, Ducrot V, Lagadic L, Ratte HT (2009) Extrapolation methods in aquatic effect assessment of time variable exposure to pesticides. In: Brock TCM, Alix A, Brown CD, Capri E, Gottesbüren BFF, Heimbach F, Lythgo CM, Schulz R, Streloke $M$ (eds) Linking aquatic exposure and effects in the risk assessment of plant protection products. Guidance from the SETAC Europe Workshop ELINK (Bari, Italy and Wageningen, The Netherlands, March and September 2007). SETAC (in press)

Kooijman SALM, Metz JAJ (1984) On the dynamics of chemically stressed populations: the deduction of population consequences from effects on individuals. Ecotoxicol Environ Saf 8:254-274

Maltby L, Arnold D, Arts G, Davies J, Heimbach F, Pickl C, Poulsen V (eds) (2009) Aquatic macrophyte risk assessment for pesticides (AMRAP). Guidance from the AMRAP workshop in Wageningen, The Netherlands, January 2008. SETAC (in press)

O'Neill RV, Gardner RH, Barnthouse LW, Suter GW, Hildebrand SG, Gehr CW (1982) Ecosystem risk analysis: a new methodology. Environ Toxicol Chem 1(2):167-177

Pastorok RA, Akcakaya HR, Regan H, Ferson S, Bartell SM (2003) Role of ecological modeling in risk assessment. Hum Ecol Risk Assess 9(4):939-972

Thorbek P, Forbes VE, Heimbach F, Hommen U, Thulke HH, van den Brink PJ, Wogram J, Grimm V (eds) (2009) Ecological models in support of regulatory risk assessments of pesticides: developing a strategy for the future. Report of the SETAC-Europe LEMTOX workshop, Leipzig, Germany, September 2007. SETAC, Pensacola (in press) 